\title{
AGRICULTURAL AND RURAL DEVELOPMENT GOVERNANCE AND COORDINATION IN BOSNIA AND HERZEGOVINA ${ }^{1}$
}

\author{
Siniša Berjan², Hamid El Bilali, Snežana Jankovič ${ }^{4}$, Adriana Radosavac $^{5}$
}

\begin{abstract}
Summary
Rural economy in Bosnia and Herzegovina (BiH) is increasingly diversified but agriculture is still important. Governance influences agricultural and rural development (ARD) policy impacts. The paper aims at analysing ARD governance and coordination in BiH. The paper is based on primary information collected by questionnaires and semi-structured interviews performed in 2011 with representatives of 120 institutions as well as a secondary data review.

Vertical coordination between State level institutions with entities, cantons, regions, municipalities and non-state actors, especially civil society ones, is still particularly challenging. Coordination between the State Ministry of Foreign Trade and External Relations; Ministries of Agriculture of the Republika Srpska (RS) and Federation of BiH (FBiH) and the Department for Agriculture of Brčko district is crucial. Participation of civil society organizations in ARD policies design and evaluation should be encouraged. Effectiveness of vertical coordination also depends on quality of horizontal coordination at RS and FBiH levels.
\end{abstract}

Key words: rural development, agriculture, governance, coordination, Bosnia and Herzegovina.

JEL: $Q 16, M 24$

1 Authors would like to thank all public institutions (e.g. MoFTER of BiH, Ministries of AFWM of $\mathrm{RS}$ and $\mathrm{FBiH}$, etc.) and civil society organizations that answered the questionnaire, provided very useful information and helped in structuring this paper.

2 Siniša Berjan, Ph.D., Faculty of Agriculture, University of East Sarajevo, Vuka Karadzica Street no. 30, 71123 Istočno Sarajevo, Republic of Srpska, Bosnia and Herzegovina, Phone: +387 57 340 401, E-mail: sinisaberjan@yahoo.com

3 Hamid El Bilali, Ph.D., Department of Sustainable Agriculture, Food and Rural Development, Mediterranean Agronomic Institute of Bari (CIHEAM-IAMB), via Ceglie Street, no. 9, Valenzano 70010, Bari, Italy, Phone: +39 08046063 60, E-mail: elbilali@iamb.it

4 Snežana Janković, Ph.D, Institute for Science Application in Agriculture, Bul. Despota Stefana Street no. 68b, 11000 Belgrade, Serbia, Phone: +381 112750 386, E-mail: sjankovic@ipn.bg.ac.rs

5 Adriana Radosavac, Ph.D., Faculty for Economy and Engineering Management, University Academy of Economy, Cvećarska Street no. 2, 21000 Novi Sad, Serbia, Phone: +381 21531 020, E-mail: adrianaradosavac@gmail.com

EP 2015 (62) 1 (95-106) 


\section{Introduction}

Bosnia and Herzegovina $(\mathrm{BiH})$ consists of two governing entities, namely the Federation of Bosnia and Herzegovina (FBiH) and Republika Srpska (RS), and one self-governing administrative unit i.e. Brčko District (BD) under State sovereignty. At the local administrative level, the country has 142 municipalities: 79 in the FBiH, 62 in RS and one in BD. The municipalities of FBiH are organized into ten cantons (Government of Bosnia and Herzegovina 2010). This institutional and political setting influences not only the design and implementation of agricultural and rural development (ARD) policies but also the governance of the whole country.

Rural economy in $\mathrm{BiH}$ is increasingly diversified, however, a significant share of households is still engaged with agriculture (e.g. Berjan et al., 2010). The primary sector is still important in $\mathrm{BiH}$ from economic as well as social viewpoints (Lampietti et al., 2009). Agriculture share in GDP was 7.40\% in 2012 (EC, 2013). According to the Labour Force Survey for 2010, the agricultural sector employs 166,000 persons i.e. $19.7 \%$ of the total labour force (ASBiH, 2010). Agricultural land covers 50\% of the total area of BiH (MoFTER, 2009). According to Bojnec (2005), 50\% of the Bosnian population rely on agriculture to a significant extent. Around $61 \%$ of the total population can be classified as rural (UNDP, 2013). Non-income indicators of poverty are extremely consistent in rural areas providing significant evidences that poverty is still largely a rural phenomenon (Lampietti et al. 2009). In BiH, most of people living in rural areas are very young or elderly with a declining economically active population (Muenz, 2007).

Evidence from many European countries suggest that there is a strong relationship between governance and rural development policies design, delivery, and most importantly, impact on rural communities' livelihoods and quality of life (e.g. RuDI, 2010).

Governance is a fashionable term that in the course of the last years has become more and more important as used in nearly every political and scientific research regarding regional development and nature conservation. It is a complex term and it used in different, complicated contexts and disciplines (Bowles, Gintis, 2002; Kohler Koch, Rittberger, 2006; Shipley, Kovacs, 2008; van Kersbergen, van Waarden, 2004; van Kersbergen, van Waarden, 2001; Ward, McNicholas, 1998).

The Institute on Governance (Graham et al., 2003) defines governance as "the interaction among structures, processes and traditions that determine how power and responsibilities are exercised, how decisions are taken, and how citizens or other stakeholders have their say". Governance comprises mechanisms, institutions and processes of decisions making and implementation through which persons and groups articulate their interests, exercise their legal rights, meet their obligations and mediate their differences (Cheema, 2005). Governance analysis focuses on the formal and informal actors involved in decision-making and implementing the decisions made and the formal and informal structures that have been set in place to arrive at and to implement decisions (Sheng et al., 2007). 
Local level governance has increasing importance for place-based rural policy. Decentralisation is granting new responsibilities to sub-national levels. Attention to placebased policies puts the accent on the role of local entities in policies implementation. New bottom-up approaches to rural development involve voluntary associations of local governments, civil society organisations and the private sector. These actors interact and become interdependent. However, vertical and horizontal coordination is crucial for the success of such undertakings (OECD, 2006).

As far as civil society organisations in $\mathrm{BiH}$ are concerned, there was a steady development after the civil war so that there were over 8,000 registered NGOs and non-profit organisations in 2004, but the number of active organisations was generally estimated to lie between 500 and 1,500 (Barnes et al., 2004). Moreover, there was a growing but uncertain number of informal community-based groups and organisations (CBOs) as well as community councils (Sterland, 2006).

The paper aims at analysing ARD governance and coordination in $\mathrm{BiH}$ at state, entity and local/municipal levels with a particular focus on the Republic of Srpska entity.

\section{Material and Methods}

The work is based on an extended analysis of secondary information and on questionnaires and semi-structured interviews performed in winter 2011 with representatives of public and civil society institutions.

The questionnaire survey focused on the design and implementation of agro-rural development policies in $\mathrm{BiH}$ and on the evaluation of coordination between the involved actors. Key questions included the operational level and the geographical coverage of each organization; the understanding of "rural development"; the involvement of the organization in a rural development policy and/or project and in which phase of the process (design, implementation/delivery, monitoring/evaluation); the level of its cooperation and coordination with other public, civil society and international organizations dealing with rural development in $\mathrm{BiH}$. Additional inquiries were about the main political, technical and strategic constraints that hamper coordination between organizations dealing with rural development and/or render it ineffective. Conflicts between the different actors were also investigated. Respondents identified also the organization that assumes, according to them, the leadership in coordinating rural development issues in $\mathrm{BiH}$. The questionnaire has been sent by e-mail to around 120 representatives of different institutions and organizations as well as international donors and cooperation agencies. In particular questionnaires were sent to key actors such as the State Ministry of Foreign Trade and Economic Relations and the Ministries of Agriculture, Forestry and Water Management (MAFWM) of the RS and the FBiH.

Additional information have been collected through open interviews and meetings with a number of independent experts (21 in total) - including local representatives, field officers and consultants of international organisations and local NGOs - and representatives of the seven selected municipalities (Pale, Istocni Stari Grad, Istocno Novo Sarajevo, Trnovo, 
Istocna Ilidza, Sokolac and Rogatica) and of the town of East Sarajevo (TES). Selected municipalities are located in Sarajevo-Romanija region (SRr, south-eastern $\mathrm{BiH}$ and $\mathrm{RS}$ ) and are characterised by a high share of rural population.

\section{Results and Discussion}

The design and implementation of ARD policies involve different supra-national or international, national and sub-national actors (regional; intermediate or sub-regional; and local), (OECD, 2006). In $\mathrm{BiH}$, intermediate levels, entities of $\mathrm{RS}$ and $\mathrm{FBiH}$, have a crucial role in ARD policies design and delivery. International organisations and development agencies have implemented different development projects and programmes during the post-war period.

In $\mathrm{BiH}$, all levels of governance, ranging from the state to municipal authorities, are involved in the agricultural sector management and rural areas development. Farmers in $\mathrm{BiH}$ are disadvantaged by a lack of government structures and institutions needed to promote and regulate markets. The state (central) government does not have a ministry of agriculture. The two entities of the $\mathrm{FBiH}$ and $\mathrm{RS}$, and Brcko district, have each retained their own separate quasi-ministerial structures (Christoplos, 2007). Agriculture and forestry issues in $\mathrm{BiH}$ are regulated at the entity levels.

At the state level the Sector for Agriculture, Food, Forestry and Rural Development (SAFFRD) at the Ministry of Foreign Trade and Economic Relations of BiH (MoFTER) deals with the coordination of international affairs, harmonisation and monitoring of donor activities, as well as the synchronisation of activities for both entities (MoFT, 2010).

The state policy in the agricultural, food and rural development sector in recent years is developed in accordance with the goals and needs for accession to the EU which is possible only with the active participation of all stakeholders in the agricultural sector. The main agriculture strategies are $\mathrm{BiH}$ Harmonisation Strategy and Operational Programme for Agriculture; FBiH Strategy for Agriculture and Rural Development; RS Strategy for Agricultural Development; RS Strategic Plan for Rural Development by 2015. During the course of 2009 the BiH Strategic Plan for Harmonisation of Agriculture, Food and Rural Development 2008-2011 along with the Operational Plan were adopted (MoFT, 2010).

Systematic and structural harmonization of agricultural policies at the state level began with entry into force of the Law on Agriculture, Food and Rural Development of BiH, adopted in May 2008. The measures of the Law are basically classified into policy measures to support agricultural markets and measures for rural development. Policy measures to support agricultural market are divided in measures to improve products quality, measures of direct support to agricultural farms and measures for foreign trade. Measures related to rural development encompass those aiming at increasing competitiveness, protecting rural environment, diversifying activities in rural areas and improving life quality in rural areas.

Moreover, the MoFTER, supported by the European Commission (EC), prepared the Strategic Plan for the Harmonization of $\mathrm{BiH}$ Agriculture, Food and Rural Development 
2008-2011 and Operational Programme for the Harmonization of BiH's Agriculture, Food and Rural Development 2008-2011. The key objective of the Strategic Plan is to provide a framework for the gradual harmonization of policies, programmes, institutions, laws, regulations, systems and services both within $\mathrm{BiH}$ and with the EU.

At entities level, institutions in charge of agricultural sector management are the Ministry of Agriculture, Forestry and Water Management (MAFWM) in the RS and the Federal MAFWM in the FBiH while Brcko District local administration has its own Department of AFWM. The Strategic Plan for Rural Development 2009-2015 was adopted in the RS (November 2009) while the Development Strategy of Agriculture, Food and Rural Development in the Brcko District was prepared in 2008 for the period 2008-2013.

Moreover, at meso and local levels there are agricultural administrations in the 10 Cantons of $\mathrm{FBiH}$ (6 ministries and 4 departments of agriculture in the cantonal Ministries of Economy) and municipalities (80 in the $\mathrm{FBiH}$ and 63 in RS).

In ARD are involved also public administrations on State or Entity level with competencies relevant for the agricultural sector; specialized institutes; NGOs and sector associations (EC, 2004). There are about 213 agricultural co-operatives in the $\mathrm{FBiH}$ of which 155 are active and 347 in the RS of which only 111 are presently reported to be active (IFAD, 2011).

Moreover, the agricultural, forestry and rural development sector is characterized by the presence of a number of international donors and financial institutions, such as the USA/ USAID, Sweden/SIDA, Italy/IC, UK/DFID, Japan/JICA, Spain/AECID, Switzerland/ SDC/SECO, Czech Republic/CzDA, the European Commission (EC), the World Bank, European Bank for Reconstruction and Development (EBRD), UNDP, FAO, etc. However from 2009, due to world economic crisis, the investments of donors in $\mathrm{BiH}$ have decreased. The sector of agriculture and forestry received $6 \%$ of total official development assistance (ODA) allocations in 2009 and 2\% of total ODA allocations in 2010. The total allocation to the agriculture and forestry sector by the members of the Donor Coordination Forum (DCF) in $\mathrm{BiH}$ was $€ 46.61$ million in 2009 . For 2010, donors have contributed $€ 13.10$ million including EC Pipeline projects for 2010 in the value of $€ 1.3$ million and the World Bank loan tranche of $€ 4.26$ million (MoFT, 2010). According to the DCF, total allocation to aid in Bosnia in 2011 was about $€ 1.503$ billion of which $€ 34.200$ million were dedicated to agriculture and forestry sector $(2.28 \%)$.

Financial support to individuals or companies involved in agriculture and rural development is provided also by micro-credit organizations and banks. Under adverse conditions, the Federal Investment Bank and the Investment Development Bank of the RS have special credit lines aimed at supporting agriculture and rural development.

In the RS in general and SRr in particular, support for rural development by municipalities is partly stated in local planning documents, which include the Local Economic Development Strategies. Many local organizations are operating in municipalities. Most of them have a predominant charity character largely due to the consequences of the civil war. Sport, cultural, youth and students' organizations are present in a large number as well. Those involved 
in ARD are mainly agricultural cooperatives, environmental associations, associations of entrepreneurs and cultural heritage preservation associations. Financial and technical support for NGOs and cooperatives is provided by local budgets. In all municipalities financial aid is guaranteed for those NGOs that are identified as organizations of public interest (e.g. organization of war veterans) while cooperatives and remaining NGOs have to submit specific projects to be eligible for funds from local and regional budgets.

Rural development strategies, plans and programmes are generally missing at local and regional level. As of 2011, only Pale municipality had a strategy for development of agriculture, while in municipalities of Istocni Stari Grad and Istocno Novo Sarajevo preparation of this document was still in progress, and the other four surveyed municipalities (Trnovo, Istocna Ilidza, Sokolac and Rogatica) did not have any strategic document related to agriculture and rural development with the exception of Rogatica where was foreseen the preparation of a Local Environmental Action Plan (LEAP). Overall in the 2006-2010 period, local development strategies focused mainly on agriculture development rather than on rural development, however the trend, generally, shows an increasing attention paid to nonagricultural activities. Nevertheless, it seems that there is a consistent lack of coordination between local institutions operating in rural areas.

The questionnaire for evaluating the level of coordination between the actors dealing with ARD policies in $\mathrm{BiH}$ encompassed the main public institutions and civil society organizations dealing with rural development in municipalities, cantons, regions, and entities as well as at the state level. Sixty-seven percent of respondents were public institutions and 33\% civil society organizations. Almost half of the respondents operate at local level (46\%), at entity level (40\%) while only less than a third $(27 \%)$ operates at the state level. Some institutions operate at two or even three levels at the same time and that explains why the sum of percentages is higher than $100 \%$. However, some differences can be noticed between public and civil society institutions. In fact, public institutions are more present at the entity level $(60 \%)$ than civil society organisations that are more present at the local level $(60 \%)$ and only $40 \%$ of them operates at the state level. Most of respondents consider rural development as a cross-sectoral issue that includes the agricultural sector.

All interviewed organizations are involved in design (67\%), implementation (73\%), and monitoring/evaluation (53\%) of agro-rural development policies. Public institutions are mostly involved in design (90\%), and less in implementation (60\%), and monitoring /evaluation (60\%). As expected, civil society organizations are fully involved in the implementation phase (100\%) and less in policy design (20\%) and monitoring / evaluation $(40 \%)$.

Almost all interviewees (93\%) had relations with public institutions while most of them have had relations with civil society and international organizations (86\%).

Sixty percent of respondents evaluate the coordination among the different actors as effective while around $20 \%$ of them evaluate it as ineffective $(20 \%$ of them did not provide any answer). The main constraints and problems impeding a good coordination between involved actors in the design and implementation of ARD policies mentioned by 
the respondents are: lack of communication among key actors; lack of qualified human resources; lack of understanding and of a common vision of rural issues and priorities; lack of clearly defined plans, initiatives and long-term strategies; absence of a dialogue culture and participatory approaches; high level of administrative and bureaucratic requirements; and delay in establishing some relevant structures (e.g. the Federal Agency for Rural Development). One of the obstacles that hamper coordination between civil society organizations and between them and public institutions is a lack of a common understanding of what is "rural" and what is "rural development".

Only 53\% of respondents identified an organization as having the leadership in coordinating rural development issues. The institutions more widely identified as the most important in coordinating rural development issues are the Entity's Ministries for Agriculture while no public institution or civil society organization considered the MoFTER as the leader institution regarding these issues. In fact, it is quite common in the decentralised or 'concerted' and multi-actors driven rural policy design and delivery systems (Mantino, 2009) that the different levels of government find it difficult to clarify their respective roles and responsibilities (OECD, 2006).

Respondents also mentioned some institutions with which they have had some conflicts. It is interesting to note that public institutions have mainly conflicts with governmental organisations and some international agencies while civil society organisations, also due to their nature, present a lower degree of involvement in those conflicts.

Overall, most of the interviewees identified the main constraints in coordination among the different organizations dealing with rural development as political (40\%), technical (60\%) and strategic (80\%).

The analysis of relations and linkages between institutions involved in the design and implementation of ARD policies in $\mathrm{BiH}$ and $\mathrm{RS}$ showed a lack and/or weakness of coordination between them. Therefore, this problem should be addressed as soon as possible in order to increase the effectiveness of these policies and their impacts on rural people's livelihoods. A basic action to strengthen coordination would be to encourage dialogue between these institutions. While "formal dialogue" does exist between some public institutions especially those operating in RS and with some international NGOs and donors, it seems that a lot need to be done in order to involve civil society and private sector organizations especially during the design and formulation phase. That is critical especially regarding the participation of rural people, farmers and their organizations. Developing strong partnership between national and sub-national governments through vertical governance arrangements and public-civil society partnering agreements can make Entity, regional and local governance institutions responsible by virtue of their participation in decision making regarding the design and implementation of rural development policies (OECD, 2006).

In order to strengthen coordination and synergy between institutions in promoting sustainable agriculture and rural development it is also necessary to harmonize entity laws and regulations with the Law on Agriculture, Food and Rural Development of the $\mathrm{BiH}$. 
Human capital has also a strategic relevance in order to achieve a good coordination between involved institutions. In fact, institutions' staff can operate in such a way to reduce transaction costs and to render communication smoother and flow of information faster. Communication should be developed horizontally, at the central, entity, regional and local levels, as well as vertically, across different government tiers (OECD 2006). Motivation and incentives to public institutions' staff can help in achieving this objective.

A better coordination between involved institutions means not only to reduce institutions operating and transaction costs but also to manage effectively incentives and subsidies provided to farmers and rural dwellers and to avoid frauds, corruption and "clientelism". A stronger partnership between Bosnian institutions dealing with rural development and those of the EU and its Member States can help ensuring a better cross-fertilization and exchange between them which can have positive impacts on their modus operandi.

\section{Conclusions}

Results of questionnaire survey show that vertical co-ordination between State level institutions with Entity, regional and local ones, especially civil society organisations, is still particularly challenging in $\mathrm{BiH}$. State and Entity governments should encourage local actor's participation in the design and implementation of place-based rural development policies. That means that governmental and public institutions should redefine their role and devise new multi-level cooperation and coordination frameworks that emphasise power sharing between the different governance levels and inter-dependence and partnership between the wide ranges of actors in ARD policy making. It goes without saying that the ease of vertical coordination between the different levels of governance also depends on the degree of horizontal coordination especially at the level of entities (RS and $\mathrm{FBiH}$ ), especially taking into consideration that respondents survey recognized Entity's Ministries for Agriculture as leading institutions in coordinating rural development issues. Coordination between the Sector for Agriculture, Food, Forestry and Rural Development of the State MoFTER; the MAFWM of RS; the Federal MAFWM (FBiH) and the Department for AFWM of Brcko District (BD) is crucial. Coordination with other state and entity ministries and development agencies is also relevant. Furthermore, survey results show that not all actors are appropriately involved in the ARD policy arena. That being said, civil society organisations, especially user ones, should be involved also in the design, and monitoring and evaluation of ARD.

Taking into consideration the questionnaire survey results, it should be highlighted that in order to increase their impact, ARD policies in $\mathrm{BiH}$ should be designed and implemented through a good coordination between multilevel governance institutions. Although good governance is not sufficient on its own it is indispensable to sustain long-term Bosnian rural territories development. In the context of rural development, good governance should not be seen as an objective on its own, but as a means to improve rural communities' living conditions by contributing to more appropriate and effective, and better coordinated services. Good rural governance is to be put into the context of a wider process of institutional reforms and rural service delivery systems encouraged by the EU and many other development agencies. 


\section{Literature}

1. Agency for Statistics of BiH (ASBiH), (2010): Anketa o radnoj snazi 2010 (Labour Force Survey 2010), ASBiH, Sarajevo, p. 38, available at: www.bhas.ba/ankete/ lfs 2010 001 01-bh.pdf

2. Barnes, C., Mrdja, M., Sijerćič, S., Popovič, M. (2004): Civil Society Assessment in Bosnia and Herzegovina, The Mission of the United States Agency for International Development in Bosnia-Herzegovina (USAID/BiH), (UDAID/BiH), Sarajevo, available at: www.usaid.ba/CivilSocietyAssessmentReportEnglishVersion.pdf

3. Berjan, S., Vittuari, M., El Bilali, H., Panin, B. (2010): Diversification of rural economy and households' livelihoods strategies in Sarajevo-Romanija region (Bosnia and Herzegovina), Proceedings, First Agronomic Scientific Symposium (Agrosym 2010), Faculty of Agriculture of East Sarajevo \& Faculty of Agriculture of Belgrade, December 9-11, Jahorina (East Sarajevo), pp. 161-167.

4. Bojnec, S. (2005): Agriculture in Post-War Bosnia and Herzegovina: Social buffer vs. development, Paper prepared for presentation at the XI EAAE Congress - The Future of Rural Europe in the Global Agri-Food System, Copenhagen, Denmark, 24-27August.

5. Bowles, S., Gintis, H. (2002): Social capital and community governance, the Economic Journal, no. 112, pp. 419-436.

6. Cheema, G. S. (2005): Building democratic institutions: governance reform in developing countries, New York, Kumarian Press Inc.

7. Christoplos, I. (2007): Between the CAPs: Agricultural policies, programming and the market in Bosnia and Herzegovina, Humanitarian Policy Group Background Paper, Overseas Development Institute, London, p. 33.

8. EC (2004): Functional Review of the Agricultural Sector in BIH, European Commission (EC), Sarajevo.

9. EC (2013): Bosnia and Herzegovina: 2013 Progress Report, European Commission (EC), SWD (2013), Brussels.

10. Government of Bosnia and Herzegovina (2010): BiH in Figures 2010, Government of Bosnia and Herzegovina, Sarajevo.

11. Graham, J., Amos, B., Plumtree, T. (2003): Principles for Good Governance in the $21^{\text {st }}$ Century, Policy Brief no. 15, Institute on Governance, Ottawa.

12.IFAD (2011): Bosnia and Herzegovina: Rural Business Development Project, Project Final Design Report REPORT No. 2460-BA, the International Fund for Agricultural Development (IFAD), Rome.

13. Kohler Koch, B., Rittberger, B. (2006): Review Article: The 'Governance Turn' in EU Studies, Journal of Common Market Studies, vol. 44, issue supplement s1, pp. 27-49. DOI: 10.1111/j.1468-5965.2006.00642.x.

14.Lampietti, A. J., Lugg, D. G., van der Celen, Ph., Branczik, A. (2009): The Changing Face of Rural Space: Agriculture and Rural Development in the Western 
Balkans, Directions in Development (DID) - Agriculture and Rural Development, The International Bank for Reconstruction and Development / The World Bank, Washington D.C.

15. Mantino, F. (2009): Typologies of governance models, FP 7 Project no. 213034, Assessing the impact of rural development models (including LEADER), funded by the $7^{\text {th }}$ Framework Programme for Research and Technology Development of the European Commission, available at: www.rudi-europe.net/uploads/media/RuDI WP3 D 3.2.pdf

16. Ministry of Finance and Treasury (MoFT), (2010): Donor mapping report 2009-2010, Donor Coordination Forum (DCF) of Bosnia and Herzegovina, Ministry of Finance and Treasury (MoFT) of BiH, Sarajevo, available at: www.donormapping.ba/pdf/DMRReport-Eng-2010.pdf

17. Ministry of Foreign Trade and External Relations of BiH (MoFTER), (2009): Policy analysis in the field of agriculture, food and rural development in BiH, MoFTER, Sarajevo, available at: www.seerural.org/wpcontent/uploads/2010/04/Analiza politika_u_oblasti_poljoprivrede_prehrane_i_ruralnog_razvoja_Bosne_i_Hercegovine Sarajevo septembar.pdf

18. Muenz, R. (2007): Aging and Demographic Change in European Societies, Main Trends and Alternative Policy Options, SP Discussion paper 0703, Social Protection, The World Bank, Washington DC.

19.OECD (2006): The New Rural Paradigm - Policies and Governance, OECD Rural Policy Reviews, Organisation for Economic Co-operation and Development (OECD), p. 168.

20. RuDI (2010): Assessing the Impacts of Rural Development Policies (incl. LEADER), Extended Policy Brief. project Funded by the VII Framework Programme for Research and Technology Development of the European Commission, available at: www.rudieurope.net/.../RuDI Extended Policy Brief 2010 06.pdf

21. Sheng, Y. K., Carrillo-Rodriquez, J., Eun-Young, L., Perez-Ludena, M., Mukherjee, A. (2007): Access to Basic Services for the Poor: The Importance of Good Governance, United Nations Economic and Social Commission for Asia and the Pacific, Study published by the UNESCAP/UNDP/ADB joint project on MDGs in Asia and the Pacific, p. 64.

22. Shipley, R., Kovacs, J.F. (2008): Good governance principles for the cultural heritage sector: lessons from international experience, Corporate Governance: The international journal of business in society, vol. 8/2, pp. 214-228.

23. Sterland, B. (2006): Civil Society Capacity Building in Post-Conflict Societies: The Experience of Bosnia and Herzegovina and Kosovo, Praxis Paper No. 9, INTRAC (International NGO Training and Research Centre), Oxford.

24.UNDP (2013): National Human Development report. Rural development in Bosnia and Herzegovina: Myth and reality, United Nations Development Programme (UNDP), Sarajevo. 
25. van Kersbergen, K., van Waarden, F. (2001): Shifts in governance: Problems of legitimacy and accountability, Social Science Research Council (MAGW), the Hague.

26. van Kersbergen, K., van Waarden, F. (2004): 'Governance' as a bridge between disciplines: Cross-disciplinary inspiration regarding shifts in governance and problems of governability, accountability and legitimacy, European Journal of Political Research, no. 43, pp. 143-171.

27. Ward, N., McNicholas, K. (1998): Reconfiguring rural development in the UK: Objective $5 \mathrm{~b}$ and the new rural governance, Journal of Rural Studies, vol. 14, no. 1, pp. 27-39, doi:10.1016/S0743-0167(97)00045-4. 


\title{
UPRAVLJANJE I KOORDINACIJA POLJOPRIVREDE I RURALNOG RAZVOJA U BOSNI I HERCEGOVINI
}

\author{
Siniša Berjan ${ }^{6}$, Hamid El Bilali ${ }^{7}$, Snežana Jankovič ${ }^{8}$, Adriana Radosavac ${ }^{9}$
}

Rezime

Ruralna ekonomija u Bosni i Hercegovini (BiH) je sve više raznolika, ali poljoprivreda je $i$ dalje važna. Upravljanje utiče na efikasnost politika poljoprivrede i ruralnog razvoja. Rad ima za cilj da analizira upravljanje i koordinaciju poljoprivrede i ruralnog razvoja u BiH. Metodologija rada je zasnovana na primarnim informacijama prikupljenim kroz upitnik $i$ intervjue obavljene u 2011. godini sa predstavnicima 120 institucija, a takođe su korišteni i različiti literaturni izvori podataka.

Vertikalna koordinacija između institucija na državnom nivou sa entitetima, kantonima, regijama, opštinama i organizacijama civilnog društva je još uvek poseban izazov. Koordinacija između Ministarstva vanjske trgovine i ekonomskih odnosa, Ministarstava Poljoprivrede Republike Srpske (RS) i Federacije BiH (FBiH) i Odeljenja za poljoprivredu Brčko distrikta je od ključnog značaja. Učešće organizacija civilnog društva u dizajnu $i$ evaluaciji politika vezanih za poljoprivredu i ruralnog razvoja treba podsticati. Efikasnost vertikalne koordinacije zavisi takođe i od kvaliteta horizontalne koordinacije na nivou RS i FBiH.

Ključne riječi: ruralni razvoj, poljoprivreda, upravljanje, koordinacija, Bosna i Hercegovina.

6 Siniša Berjan, Dr., Poljoprivredni fakultet, Univerzitet u Istočnom Sarajevu, Vuka Karadžića 30, 71123 Istočno Sarajevo, Republika Srpska, Bosna i Hercegovina, Telefon: +387 57340 401, E-mail: sinisaberjan@yahoo.com

7 Hamid El Bilali, Dr., Department za Održivu Poljoprivredu, Prehranu i Ruralni razvoj, Mediteranski Agronomski Institut iz Barija (CIHEAM-MAIB), via Ceglie 9, Valenzano 70010, Bari, Italy, Telefon: +39080 46063 60, E-mail: elbilali@iamb.it

8 Snežana Janković, Dr., Institut za Primenu Nauke u Poljoprivredi, Bulevar Despota Stefana 68b, 11000 Beograd, Srbija, Telefon: +381 112750 386, E-mail: sjankovic@ipn.bg.ac.rs

9 Adriana Radosavac, Dr., Fakultet za Ekonomiju i Univerzitetski Menadžment, Univerzitet Privredna Akademija u Novom Sadu, Cvećarska 2, 21000 Novi Sad, Srbija, Telefon: +381 21 531 020, E-mail: adrianaradosavac@gmail.com 